Vol. 18, $n^{\circ} 1 \mid 2014$

Varia

\title{
Police reform and the transnational circulation of police models : The Portuguese case in the $1860 \mathrm{~s}$
}

\section{Gonçalo Rocha Gonçalves}

\section{(2) OpenEdition \\ 1 Journals}

Electronic version

URL: http://journals.openedition.org/chs/1461

DOI: $10.4000 /$ chs. 1461

ISSN: 1663-4837

Publisher

Librairie Droz

Printed version

Date of publication: 1 July 2014

Number of pages: 5-29

ISBN: 978-2-600-01935-4

ISSN: 1422-0857

\section{Electronic reference}

Gonçalo Rocha Gonçalves, «Police reform and the transnational circulation of police models : The Portuguese case in the 1860s ", Crime, Histoire \& Sociétés / Crime, History \& Societies [Online], Vol. 18, $\mathrm{n}^{\circ} 1$ | 2014, Online since 01 July 2017, connection on 17 March 2020. URL : http:// journals.openedition.org/chs/1461; DOI : https://doi.org/10.4000/chs.1461 


\title{
The Herman Diederiks Prize Essay for 2013 Lauréat du prix Herman Diederiks 2013
}

\author{
Police reform and the transnational circulation of police models: \\ The Portuguese case in the $1860 \mathrm{~s}^{1}$
}

\section{Gonçalo Rocha Gonçalves²}

\begin{abstract}
Cet article étudie la réforme du système policier portugais au cours des années 1860. À cette époque, la nature des institutions policières, leurs fonctions et leurs pratiques devinrent une question politique majeure, dans le contexte du mouvement de réforme qui culmina, en 1867, dans la fondation de la police civile dans les villes, mais échoua à mettre en place une gendarmerie nationale. On ne peut cependant réduire cette réforme à son aspect institutionnel, car ce sont d'une part les fonctions policières qui étaient en cause - avec l'apparition de la notion nouvelle de "sécurité publique» - et, d'autre part, les logiques des pratiques, avec les nouveaux principes directeurs de "prévention» et d' "urgence». En conclusion, l'article insiste sur le fait qu'au Portugal, ce sont la culture politique et la circulation des modèles policiers entre différents pays qui, davantage que la préoccupation pour les questions de désordre et de criminalité, expliquent la réforme de la police.
\end{abstract}

This article examines the reform of the Portuguese police system during the 1860s. In this period, the nature of police institutions, functions and practices became a main political issue with the reform movement culminating in the founding of Policia Civil in urban settlements in 1867 while failing in a project to establish a national gendarmerie. However, this still represented more than just institutional reform; at stake was a re-examination of police functions, with a new notion of 'public safety' and the rationales behind policing practices, with 'prevention' and 'emergency' as the new guiding concepts. The article concludes that in Portugal, the political culture and the circulation police models between national jurisdictions provide better explanations for police reform than actual concerns about disorder and crime.

\footnotetext{
This research was supported by a doctoral grant from the Fundação para a Ciência e Tecnologia - FCT (SFRH/BD/43217/2008) and is part of the collective project funded by FCT "Unveiling police(men) histories : urban policing in Portugal, 1860-1960" (PTDC/HIS-HIS/115531/2009). My thanks to Paul Lawrence, Clive Emsley, Nuno Madureira and Susana Durão for commenting on earlier drafts of this article and for their support in developing my doctoral research.

2 Gonçalo Rocha Gonçalves, Post-Doctoral researcher at Centro de Estudos de História Contemporânea / ISCTE - Lisbon University Institute. PhD from The Open University, Minton Keynes, (2012) with the thesis "Civilizing the police(man): police reform, culture and practice in Lisbon, c.18601910". Latest publications: "Polícia, ordem pública e 'novas' formas de vigilância: as dinâmicas e os dilemas da segurança", Análise Social, 2012, XLVII (3), 204, pp. 713-723; "Preleções, teorias e as dinâmicas da formação dos polícias civis em Lisboa, c.1870-1910", Revista de História da Sociedade e da Cultura, 2012, 12, pp. 323-342.
} 
The nineteenth century was characterised by major police reform processes across Europe. As the century progressed, one of the most significant aspects of these reforms was how the adoption of new measures in many countries were increasingly influenced by what was happening elsewhere. Whether emulating or rebuffing foreign examples, knowledge about police systems in other countries played an increasing role in shaping reform projects. Thus, the reform of European police systems became a progressively interlinked process. ${ }^{3}$ In Portugal, 1867 saw police reform attain one of its most significant moments when new police forces were set up in Lisbon and Oporto: the Polícia Civil which was later expanded to all district capitals, as well as the failed attempt to establish a national gendarmerie. In the context of wider debates about the nature and form of the state and its role in society, the reform of the police also emerged strongly influenced by perceptions of foreign models. Focusing on the Portuguese case, this article seeks to examine police reform while pointing to the importance of this transnational circulation of European police models in shaping both the debates and the measures adopted.

Although police reform in Portugal was initiated later than in other countries, it followed a similar pattern. Clive Emsley summarises the common characteristics acquired by European police institutions during the nineteenth century in three idealtypes: civilian police forces controlled by the central government and normally deployed in cities; municipal civilian police controlled by the municipalities; and national, military police forces also controlled by the central government and normally deployed in rural areas. ${ }^{4}$ The model for urban police force was the Metropolitan Police of London and its Bobbies. ${ }^{5}$ The Guardie di Publica Sicurezza founded in Piedmont in 1852, the reform of the Parisian police in 1855, or, as will be seen in this article, the establishment of the Polícia Civil in Portugal in 1867 all stand as examples of measures linked to a broader transnational process that took the Metropolitan Police as its model. Outside major cities, the French gendarmerie model, 'bringing the state to the countryside', had taken hold in continental Europe since the Napoleonic Wars. The Carabinieri, founded in Piedmont in 1814 and expanded to all of Italy following unification, the creation of the Guardia Civil in Spain in 1844 or, we shall return to, the failed attempt to establish a Guarda Civil in Portugal in 1867 all fell within the scope of a similar process. ${ }^{6}$ However, the concrete experience of this cross-fertilisation process, particularly outside the main European countries, remains a poorly explored subject.

The discussion in Portugal was correspondingly framed within the context of consolidating a dual system: civilian versus military, urban versus rural, which would also dominate Continental Europe police systems over the course of the century. In fact, it was the very awareness of this duality among Portuguese politicians and the desire to emulate the 'modern', 'civilised' and 'efficient' examples encountered abroad became the essential guide for attempts to reform the police. The circulation of the idea of the English 'bobby' or the French 'gendarme' was by the mid-nineteenth century still a novelty but was made possible by the communication revolution

Denys (2012).

4 Emsley (1999a).

5 Emsley (1983, pp. 53-75, 2007); Lawrence (2011, pp. xx-xxi); Hughes (1996); Deluermoz (2009).

6 Emsley (1999b). 
which facilitated the circulation of people and information. ${ }^{7}$ Only from the $1830 \mathrm{~s}$ could Portuguese politicians and journalists discuss in a more informed way the police systems whether of London or Paris, rural Spain or Italy. This generation had travelled abroad more than any other previous generation, and they were the first to read not only foreign newspapers on a regular basis but also local newspapers in which the 'foreign section' became increasingly expanded by news circulating via the telegraph. Just how this change affected police reform in Portugal constitutes the main objective of this article. It can be traced through parliamentary debates, in the correspondence from the Ministry of the Interior and in the press.

Police historians have also noted that alongside institutional change, police reform also involved deeper transformations, in terms of changes to the organisational framework as well as to policing practices. ${ }^{8}$ Although institutional change was the most visible aspect of the political project of police modernisation, it also encompassed a more profound re-conceptualisation of how the new policing methods were to be organised and which approach should prevail in the interactions with the citizens. By examining police reform in Portugal during the 1860s, we see how this represented a threefold process that incorporated institutions, organisations and policing practices.

After this introduction, which concludes with a brief description of police reform in Portugal from the late eighteenth century to the early 1860 s, the next section analyses how police reform appeared on the agenda of successive governments and identifies the contours of the various proposals. This is followed by a section focusing on the debates about the institutional and organisational implications of the proposed reforms. A third section investigates the repercussions of these reforms for the functioning of police and discusses how 'public safety' became a category under which multiple actions were initiated. The final section demonstrates how the transformation of the police system also led to changes in the rationale behind police action by shaping notions of how policemen ought to act and perform their roles as police agents.

Like many other countries in continental Europe, the 'police' was at the core of state reform during the eighteenth century. The Intendência Geral de Polícia (IGP) was set up in the wake of the 1755 earthquake in Lisbon and the reconstruction efforts that followed in 1760. Embodying the cameralist notion of police, the IGP was not only responsible for the repression of crime and the control of public order but also took on a panoply of functions including street-lighting and public fund raising for theatres and scholarships to study abroad. Nevertheless, the IGP was essentially a bureaucratic office without any operational capacity to enforce police regulations. The Guarda Real de Polícia (GRP) was first established in Lisbon in 1801 to overcome this operational problem and was soon extended to Oporto. This was a military police force undertaking patrols throughout the city. As it was formally controlled by the army, this often led to conflict with the leadership of the IGP. Following the expulsion of the Napoleonic forces, the system remained the same: the IGP with broadly defined police functions but with the GRP patrolling the streets. ${ }^{9}$ The first Portuguese liberal experience (1820-1823) did not lead to rupture

\footnotetext{
Knepper (2010, pp. 12-42).

8 Johansen (2007, p. 49); Liang (2002, p. 4).

9 Lousada (2005).
} 
and transformation within the police system. Despite debates about the urgency of reforming the police and criminal justice system, the notion of 'police' as it was conceived in these debates still owed more to the earlier tradition than to concepts of the police as a force charged with maintaining the domestic peace. ${ }^{10}$

Only after the ultimate victory of the liberal faction in 1834 did the institutional and organisational police framework experience effective changes. This year saw the founding of the Guardas Municipais in Lisbon and Oporto. Despite their name, they were directly controlled by the central government. Furthermore, whilst their name was directly influenced by the similarly named Parisian institution, they were designed in the image of the London Metropolitan Police: urban, civil police forces controlled by the central government. For Portuguese politicians, this influence was not altogether strange. In 1829, while Robert Peel was trying for the second time to convince the British Parliament that the creation of a centralised non-military police force was the best way to ensure citizen safety without endangering English liberties, hundreds of Portuguese liberal refugees lived in the country and would have followed the intense debates in Parliament. ${ }^{11}$ The internationalisation of the debates on police reform had roots in the biographical experience of the Portuguese liberal political elite which, after 1828, was forced into exile by the absolutist regime of Miguel I. The experience of living in foreign countries like Britain or France proved pivotal in providing direct experience of other police models and approaches to policing. ${ }^{12}$ In 1855, Rodrigo da Fonseca Magalhães, then Minister of the Interior, recalled the founding of the Guarda Municipal, originally planned by him: "I did not invent anything", he argued, "I aimed to copy the organisation of London's police...I tried to divide the body into sections according to the different neighbourhoods, delegating control to a general director...It was a purely civilian organisation, only with a badge, a round hat [and] a blue coat....". ${ }^{13}$

Regardless of its initial configuration, the Guarda Municipal underwent an irreversible process of militarisation during the unstable years of the early liberal regime. The Public Safety Corps were launched in 1838 to police the country outside Lisbon and Oporto. It was a military police corps organised in every national district and controlled by the Governadores Civis [the Portuguese version of the French $\operatorname{Préfet}(s)$ ]. Although recognised as a useful tool for security and administration, the state experienced difficulties in effectively controlling these bodies. Central government ultimately dictated the abolishment of these corps, which was then followed by the reaffirmation of the role of the regular army policing. ${ }^{14}$ At the beginning of the second half of the nineteenth century, the Portuguese police system thus consisted of military police forces in the two largest cities and small detachments of the regular army policing the countryside. In addition, some policing functions were undertaken by the state administration, composed of civil governors and municipal administrators. At the base of the pyramid, there were the "unpaid

10 See, for example, the lengthy report on public safety presented by the Minister of Justice (and not the Interior Minister) to the parliament in Diário das Cortes da Cortes Gerais e Extraordinárias da Nação Portugueza, 1822, Tomo VIII, pp. 55-73.

11 Philips (1980).

12 On the effects of exile on the political learning of Portuguese liberals, see Vargues (1998, pp. 67-76).

13 Diário da Câmara dos Deputados / Parliamentary Debates [DCD], 22-5-1855, p. 292.

14 Cerezales (2008, pp. 53-75). 
agents of administration', the Regedores and Cabos - men chosen at the parish level to perform policing duties without receiving any remuneration.

Police reform was always intrinsically linked with the post-1834 emergence of a liberal political regime in Portugal. However, this was to prove a tortuous process. Prior to 1851 , the inability of the different political factions to accept some of the fundamental rules of the political game established by the Constitutional Charter (the reserve power exercised by the queen, elections and their results, etc.) led to constant political instability. When in opposition, neither the conservative-leaning nor the radical factions accepted the legitimacy of the other. This often led to conflicts that descended into political violence. The year 1851 marked the beginning of the stabilization of the political system, when the so-called Regeneration movement came to power. Although initially undertaken by the military, the leadership of the movement was rapidly taken over by civilian politicians. The 1852 constitutional reform, which instituted direct suffrage, achieved a minimum level of consensus within the Portuguese "liberal family". The 1850s thus constituted a watershed moment in Portuguese liberalism with attention now focused on generating economic progress. The government was mostly in the hands of the conservativeleaning party, the Regenerador, but the other main party, the progressive Histórico, also held power for some periods. An intense program of public works - in which the railways became one cornerstone - then took centre stage in national political life. By the end of the decade, however, the first signs of tension in the hitherto relatively peaceful political environment began to emerge. The growing politicisation of middle and even working classes in urban areas as well as widespread resistance to growing state interference in the social and economic spheres turned the 1860s into a tumultuous decade. As we shall see, the debates on police reform that emerged were profoundly affected by this political environment.

\section{POLICE REFORM ON THE PORTUGUESE POLITICAL AGENDA DURING THE 1860S}

On Christmas Day 1861, the streets of Lisbon were seized by a mob and unusual levels of tumult and turbulence spread across the city. This was the culmination of the climate of tension that had persisted since the beginning of 1861 with the emergence of the Associação Patriótica (AP), a left-wing, proto-socialist political association. In addition the death of the king and two of his brothers in the early days of November, officially because of miasmatic infection, led to rumours of them having been poisoned by members of the government. The Christmas Riots, as they became known, triggered a government reaction that returned policing to the political agenda. After the acclamation of the new king, Luís I, on 22 December, the AP called a rally on Christmas Day. During the morning of that day, a crowd gathered in the city's main square. Tensions grew as the protesters decided to send a delegation to the Ajuda palace where the new king and his father were staying. On their way to the palace, some association members decided to enter the nearby Town Hall to call upon the councillors to join the delegation thus granting the protest greater symbolic power. By this stage events could already be characterised as a 'mob' forcibly entering the Town Hall and disrupting an on-going meeting. What followed was a lively meeting between protesters and the city council, which was also attended by the Civil Governor and other government authorities. This, 
however, failed to prevent the events from descending into a riot. At the end of the tumultuous meeting, protesters and authorities headed towards the palace. Afterwards, commentators criticised the non-intervention of Guarda Municipal at this crucial moment. When the crowd arrived at the palace, the king's father, Fernando, tried to calm the protesters from the window. The crowd cheered the king and his father but started hurling abuse at the politicians. Already by late morning, the protesters began to disperse into small groups and headed back towards the centre of the city. The situation seemed under control but late in the afternoon groups gathered in the streets around the Ministry of Finance before forcing their way into the building. Ávila and Loulé, two senior government officials who were then in the building, fled in fear to the adjacent Navy Arsenal. During the night, chaos spread throughout the city and mobs set out in pursuit of the 'reactionaries'. Although the homes of prominent politicians, such as Loulé, Ávila, Martens Ferrão and others, were attacked, the police authorities did nothing to intervene. Only on the following day did the army take up position in Praça do Comércio. The day went on with the populace staring at and occasionally jeering the soldiers. ${ }^{15}$

With tension still running high two days later, Prime Minister Loulé submitted a proposal to parliament for establishing "civilian police forces" in charge of maintaining order and public safety in Lisbon and Oporto. The four brief articles that constituted the proposal added very little to clarify the government's intentions. The preamble of the proposal did indicate some guidelines including the need for a new police force stemming from the inability of non-professional police agents and the military to guarantee that peace and tranquillity prevailed. This inability was explained in terms of lack of professionalization: “...police service requires learning and a special education; it needs long practice and, it needs to be said, a certain vocation" from devoted agents. ${ }^{16}$ Following this, the project had to wait for parliamentary discussion and approval.

Almost a month later, on 21 January 1862, Parliament began discussing a report on the events of Christmas 1861. After many years where references to police reform appeared only very occasionally in parliamentary debates, the discussion of this report suddenly re-established police reform on the political agenda as a key political issue requiring urgent measures. However, more than a mere response to the riots, the debate essentially highlighted the need to reorganise the police system in keeping with the needs and requirements of a liberal political regime. Although triggered by the riots, the discussion about police reform was not merely a response to them. Lobo D'Avila, a politician on the political left, warned: "We need to organise the police more adequately. This is an aspect of governance that has been left in the most complete oblivion and neglected by all our governments... we have always relied on the good character of the Portuguese people". ${ }^{17}$

The report was approved by the lower chamber but led to a stalemate with the upper chamber in what was widely perceived as a defeat for the government. As a direct consequence, the government was reshuffled with some ministers being replaced in February, thereby delaying the urban civil police project discussion and vote. In March 1862, a member of parliament submitted a request for information

\footnotetext{
15 Cerezales, (2008, pp. 90-104).

16 DCD, 27 December 1861, p. 5288.

17 DCD, 25 January 1862, p. 280.
} 
about what had already become the almost forgotten police project and received no response..$^{18}$ One month later, the same parliamentarian insisted on a debate on the question. On behalf of the parliamentary committee on public administration issues, Sá Nogueira responded that the matter was still awaiting development due to the change in government. ${ }^{19}$ In June, Sá Nogueira himself asked the Interior Minister about the project. However, Nogueira, who was a government supporter, already knew more than most other politicians; his own question referred to a undeveloped project to reform the police, not only in Lisbon and Oporto, but nationwide. The minister replied accordingly, asserting that he was studying the question and new projects would be presented to Parliament by the beginning of the following year. ${ }^{20}$ Hence, from December 1861 to June 1862, the debate shifted from a circumscribed reform of policing in the cities of Lisbon and Oporto to reform of the national police system which included plans to set up a nationwide rural police force.

This was neither totally surprising nor out of context. In early 1862 there had been a series of tax-riots and violent opposition to a cadastral survey both in the Northern provinces of Minho and Trás-os-Montes and on the Atlantic islands of the Azores. Authorities all over the country had failed to respond to the repeated popular resistance to property tax rolls and the new weights and measures laws as well as constant breaches of the 'principle of authority'. ${ }^{21}$ Moreover, construction had begun of railway lines across the extensive rural areas of southern Portugal. Large numbers of workers were billeted into improvised camps on open fields and in small towns with predicable consequences of public disorder. The correspondence received and sent from the Ministry of Interior reported increasing frequency of conflict both among workers and between workers and local populations..$^{22}$ It was in this context that the need was expressed for a rural police force extending throughout the country, which explains its sudden entry onto the political agenda.

These expectations were not fully met in 1863. It was already May, with the parliamentary session already well under way, when Anselmo Braamcamp, Minister of the Interior, put forward a new proposal to establish a civilian police force but now only for Lisbon. ${ }^{23}$ Although his plans were more developed than the previous project, its most significant aspects were the unambiguous affirmation that the Guarda Municipal and the new police force together were to make up the city's police system. He also indicated that the latter would be subject to control by the Civil Governor. This project was the public and formalised expression of the government's political will to reform the public safety system. However, as already hinted, plans for a more comprehensive reform of the police system were already being sketched out behind closed doors. Subsequently, in October 1865, the General Secretary of the Interior Ministry reported to Braamcamp's successor as Interior Minister Martens Ferrão that Braamcamp had in fact submitted a draft proposal to establish a national gendarmerie in 1862 , but that it had been rejected by the

\footnotetext{
18 DCD, 01 March 1862, p. 672.

19 DCD, 26 April 1862, p. 1110.

20 DCD, 09 June 1862, p. 1601.

21 Cerezales (2007).

22 Arquivo Nacional Torre Tombo - Ministério Reino / Portuguese National Archives - Ministry of Interior Archive [IAN/TT-MR], Lv.1686.

23 DCD, 10 June 1863, pp.1839-1840.
} 
Finance Minister on the grounds of being excessively expensive. ${ }^{24}$ Whatever the plans, they suffered from the prevailing governmental instability. Constant political turbulence throughout 1863 saw the government weakened by systematic attacks which again had the effect of bringing all police reform plans to a halt. Nevertheless, parliament had not forgotten the matter. Already in 1864, Martens Ferrão, then still just an important figure on the opposition benches, called on the government to "look urgently at the reform of the public safety system." 25

The opportunity to resurrect police reform as a political issue came with the International Industrial Exhibition, inaugurated in Oporto in September 1865. The Agência Policial Portuense (Oporto Police Agency), which was founded especially for this event, provided an opportunity to put some of the ideas into practice which had been discussed over the past few years. The exhibition held a strong symbolic meaning for the state and its desire to prove its ability to modernise the country. These exhibitions were very much in vogue in Europe during this period and constituted showcases of modernity, not only in terms of the exhibitions themselves but also in everything that surrounded them. The connection between these types of event and police modernisation was indeed not specific to Portugal. The Universal Exhibition in London in 1851 represented a pivotal moment in the national and international affirmation of the Metropolitan Police. ${ }^{26}$ And with the impending Paris Universal Exhibition a few years later in 1855, Napoleon III sent a commission to Britain to study the London police model. ${ }^{27}$ As Oporto prepared for this great moment of 'civilisation' and 'progress', a modern police force clearly featured as part of the project.

With Oporto's Guarda Municipal still in operation, the new force took to the city's streets for the opening of the exhibition in September 1865. The police force was under the authority of the Civil Governor and consisted of 140 men in blue uniforms and armed only with a small sword. Its head 'office' was located in the city's Town Hall with its functions defined as dealing with the "urgent needs' of visitors and ensuring the security of individuals and due propriety." ${ }^{28}$ On the Exhibition opening day, one case reported in the newspapers portrayed how the Portuguese police system was seen as backward in relation to other - 'civilised' and 'European' - examples. A cavalry patrol from the Guarda Municipal attempted, at a steady trot, to disperse a crowd gathered in a nearby square to see the visitors arriving and leaving everybody "filled with fear" and "causing many to fall and be run over". ${ }^{29}$ The newspapers reported this as a clear example of old-fashioned policing, with police forces making indiscriminate use of force. In contrast, and though still to arrive in Portugal, examples of good policing were conveyed by the newspapers through references to foreign policing, mainly French and British, as practices requiring specific techniques to avoid unnecessary force and thus earning popular respect. When the Exhibition closed in early 1866, the number of police agents employed was cut back. However, given that it had been generally well

\footnotetext{
24 IAN/TT-MR, Mç.3035, L ${ }^{\circ} 15, \mathrm{~N}^{\circ} 1761$.

25 DCD, 23 May 1864, p. 387.

26 Smith (1985, pp. 89-93).

27 Deluermoz (2009, p. 439).

28 O Nacional, 14 October 1865.

29 O Nacional, 19 September 1865.
} 
acceptance and contributed to the modern image in the city, the new Minister of the Interior, Martens Ferrão, decided the unit should remain in operation. In June 1866, parliament discussed the allocation of funds that had already been spent on the agency and set the budget for the following year. It transpired that reform of the entire police system was again - or more accurately still - on the government's agenda. Criticising the high cost of this police force, a prominent figure on the opposition benches, Carlos Bento, exclaimed "I do not understand very well why this body of police is to be kept. For the experiment of what, Gentlemen?"30 The experiment - the 'test' - which was still very much on-going, was a 'purely civil' police force.

The new government, in which Martens Ferrão was a key figure, proved significantly more resilient than its predecessors. The 'fusion' government, as it became known, was an alliance between the two main political parties Regenerador and Histórico - intended to continue the public works programme (roads and railways) and focus on economic development. The sense of political self-security partly explains the audacity of the government proposals emerging, in particular from the Ministry of Interior. In between a new administrative code and the reform of public education, Martens Ferrão submitted a proposal on 31 January, 1867 to establish civil police forces in Lisbon, Oporto and all other national district capitals. The new police forces in the two largest cities would be paid for directly by the state with the costs of the other forces met by district monies, i.e. generated by contributions levied on all the municipalities in the respective district. The proposed bill also extended to a new form of countryside policing, the guardas campestres. Adopting a direct translation of the French gardes champêtres, these men were paid for by the municipalities and held municipal police duties. A few days later, the government presented parliament with a proposal to establish the Guarda Civil. ${ }^{31}$ With its name copied from the Spanish gendarmerie, this was a national military police force operationally deployed in service of the civil authorities. Overall, these proposals amounted to a radical transformation of the Portuguese police system. Of further significance is how this chain of events was no longer an extemporaneous proposal made in the heat of the moment, as in December 1861, but an overall project designed to reform the public safety system after having been thought through, studied and matured over the intertwining years. Reflecting a factor common to all discourses of the time, Martens Ferrão clearly expressed that evidence of the need to reform the police system was decisively supported by comparisons with other European examples. After the fall of the government in January 1868, which meant the abandoning of the gendarmerie project among other consequences, Martens Ferrão would recall :

But who dares now to speak on the Civil Guard?!... Every nation from the moment one reaches Badajoz [the first Spanish town across the southern border] until arriving in Russia. Find a nation in Europe that does not have its Civil Guard, or its Gendarmerie, or its king's Carabinieri? Everywhere is the same. I compiled the regulations of this service in the main nations. I studied all these organisations, [and] except for the one there is in England, which is different, they are [all] based on the principles that governed the structuring of the French gendarmerie, with the

\footnotetext{
$30 \quad$ DCD, 05 June 1865, p. 1811.

31 DCD, 06 February 1867, pp. 549-551.
} 
only difference being Spain, which makes no distinction between the police force in the capital and in the provinces. ${ }^{32}$

In fact, due to the practically revolutionary nature of many of the government's proposals, the political atmosphere in 1867 was the fieriest since the beginning of the Regeneration period in 1851, with numerous and large meetings, a novelty for the time, taking place throughout the country. The government's ambitious reform programme resulted in great resistance almost everywhere in the country. The most hotly debated contemporary issue focused on public finances. State expenditure had grown steadily over the previous decade without any corresponding increase in revenues. The risk of state bankruptcy was high. To further trouble this scenario, the new administrative code contemplated the abolition of six districts and numerous municipalities while boosting the supervisory powers of the central government under the maxim: political centralisation and administrative decentralisation. The founding of the Guarda Civil featured among the more contested measures during 1867 because of its sheer cost. Partly as a result of this street pressure, but also due to the busy parliamentary schedule, debate of the Guarda Civil project got postponed to 1868 . The Polícia Civil project was approved more smoothly in June and promulgated by the king in early July. No time was wasted and in the second half of 1867 the new police forces were set up in both Lisbon and Oporto. Recruitment began immediately on publication of the law and extended through to October 1867 . In early 1868 , the new police took to the streets of both cities. In December, new taxation and administration laws were promulgated and supposed to come into effect on New Year's Day. However, a movement of the commercial elite in Oporto flatly refused to accept the new laws. The Janeirinha, so called because the movement began on 1st January, resulted in the government falling. Almost all of the controversial laws were abandoned by the incoming government, including the Guarda Civil project. ${ }^{33}$ The Polícia Civil was maintained but probably only because it was already in effect.

\section{DISCUSSING POLICE INSTITUTIONS AND THE NEW POLICEMAN}

Following this summary of political events that culminated both in the launch of the Polícia Civil in Lisbon and Oporto and the abandonment of the Guarda Civil project, this article now moves to address the key aspects at stake in the various police reform proposals over these years. Drawing now more intensively on evidence collated from the archives of the Ministry of the Interior, this aims to emphasise how police reform debates were not limited to Parliament and the press but also occupied a central position within the state bureaucracy. In January 1865, for example, the Oporto Administradores de Bairro (neighbourhood administrators), administrative posts appointed by the central government and overseen by the Civil Governor, sent the Civil Governor a proposal to set up a 'public safety force'; this was justified both in the light of the upcoming International Exhibition as well as their own frustration with critical 'public opinion', which they claimed only existed

\footnotetext{
32 DCD, 14 May 1868, pp. 1090-1091.

33 Cunha (2003).
} 
"because [the newspapers and public opinion] did not even imagine that 'police' [in Oporto] is not more than but a word". The Civil Governor subsequently forwarded the proposal to the Interior Minister. In the accompanying report, they lengthily described and discussed the causes of the inadequate conditions of the city's police. A few months later, in October 1865, the Civil Governor of Lisbon presented the Ministry with a plan for its own 'civil police force'. Simultaneously, the ministry's own internal services were producing a long report on the history of police reform since December $1861 .{ }^{34}$ Indeed, the analysis of problems and proposals for their resolution took place predominantly within the state apparatus and reveal the contours of the on-going debates.

A first and central issue in this dispute was the deployment of the military to perform police functions. ${ }^{35}$ The military character of the Guarda Municipal in Lisbon and Oporto came in for criticism because, in the opinion of the Oporto neighbourhood administrators, these forces "do not require that the soldiers act to enforce transgressions and municipal bylaws." 36 Oporto and Lisbon public authorities described the practices of Guarda soldiers as reacting only to incidents of disorder and not getting involved in the minor problems and issues of everyday urban life. The subject also came up for discussion on the pages of the Portuguese army's own official publication. Rejecting the arguments of civilian critics, the army paper stated that the Guarda Municipal represented an "extremely strong anchor of authority". Furthermore, in direct response to the proposal to set up civilian police forces in Lisbon and Oporto in December 1861, the paper maintained that despite the "influx of freedom" in recent decades, the Portuguese remained unprepared for the civilisational progress as encapsulated by 'English policeman' ${ }^{37}$ This type of civil authority represented by the new police would, the military publication assured, fail to gain popular respect and would thus jeopardise the public peace. The argument was not new; it had indeed been central to the militarisation of the Guarda Municipal in the 1830s. Recognising to some extent the validity of the army's position, both the government's police proposals of 1863 and 1867 were clear: a military police force would always remain in the two cities, whether the Guarda Municipal or the national gendarmerie.

Another factor to the debate on the military as police involved their deployment for policing tasks in rural areas. However, the contours here differed: it was not a question of whether or not to use the military for policing functions but rather of how to use them best. Paying civilian policemen cost more than paying ordinary soldiers and whilst the costs of civilian police was judged worthwhile in the main cities - indeed, because of the complexity and heterogeneity of urban life and society they were perceived as necessary - deploying the military was a consensual solution for the rest of the territory. Instead, debates revolved around just how the rural military police service would best be put into operational service. Over the years, the regular army had been distributed across the territory in detachments of variable sizes. However, the forces available were not distributed according to any rational

34 IAN/TT-MR, Mç.3035, L L $15, \mathrm{~N}^{\circ} 1761$.

35 IAN/TT-MR, Mç.3037, L ${ }^{\circ} 16, \mathrm{~N}^{\circ} 42$.

36 IAN/TT-MR, Mç.3027, $\mathrm{L}^{\circ} 15$, without number.

37 Revista Militar, Tomo XIV, nº 15 January 1862, pp. 11-16; № 2, 31 January 1862, pp. 41-46. In english in the original. 
pattern but were routinely deployed on an ad hoc basis depending on factors such as threats to the public order or pressures from local notables. ${ }^{38}$ Criticism of this rather chaotic system had grown over the years. In 1862, when the army budget was under discussion in Parliament, Martens Ferrão criticised the effectiveness of the army in performing policing tasks, which he stated had resulted in a situation where there was "neither police nor army, and safety is not a reality". ${ }^{39}$ It was a double-edged sword. On the one hand, the system was causing disciplinary problems in the army as the deployment of small detachments throughout the country undermined effective control through the military hierarchy. On the other hand, and as a consequence of this organisation of rural policing, the ordinary soldiers from these detachments were unable to meet minimum expectations to policing effectiveness. This also caused widespread public criticism. The creation of a gendarmerie was thus the answer to this dual problem: freeing the regular army of the burden of policing and addressing the problems this caused to military discipline while also increasing policing effectiveness.

A significant proportion of Portuguese policing in this period still fell to part-time policemen : regedores and cabos de polícia. These were men chosen at the parish level to serve for one or two years. They were charged with every kind of administrative and policing task, ranging from guarding the municipal and provincial treasuries to escorting prisoners on their way to central prisons or courts in neighbouring parishes. The increasing need to reform the existing police structures also arose from criticisms of this type of police agents. The number of cabos de polícia, which provides a good indicator of the real extent of this form of policing, fluctuated between twenty and thirty thousand nationwide. However, as noted by Catroga, not only was the appointment of these officers not a homogeneous process in either time or space, but they could also not be considered 'employees' in the modern and bureaucratic sense of the term. ${ }^{40} \mathrm{~A}$ random, impressionistic look through the contemporary daily press serves to convey how regedores and cabos de polícia did in fact perform numerous policing tasks: they may have been almost unanimously criticised but they were there on the ground performing police functions. As shown by Santos in a study on an Oporto parish, the action of the cabos stretched well beyond mere intervention in elections as was popularly perceived. ${ }^{41}$ Across the country, these men were engaged in patrolling the streets, policing fairs and markets, acting as prison guards and transporting convicts. According to the neighbourhood administrators in Oporto, regedores and cabos in theory had a "multitude of tasks" to enforce, however by "calling on those to police who constantly need to work during the day to be able to eat at night, one simply cannot expect to combat crime". ${ }^{42}$ Furthermore, according to the Oporto authorities, these were not very popular posts; regedores and cabos only accepted them as a sign of "mere obedience" without "showing any zeal for public affairs" and sometimes "witnessing disorder with indifference". However, "we still owe them for their valuable services, and without their assistance the Guarda

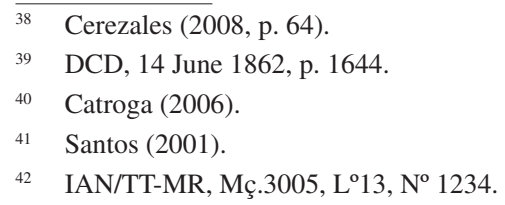


Municipal would serve of little purpose". ${ }^{43}$ However, in general, central government did not trust individuals over whom its control was doubtful, to say the least.

Although rural policing had long since been integrated into the police reform process, it was the police of Lisbon, the political capital, which was always going to be the trigger for reform. In addition, as a result of the criticism of military and part-time police agents the discussion was focused to a great extent on the particular idea of a policeman. In 1867, the parliamentary committee in charge of revising the Polícia Civil law proposal drew up an ideal profile of their expectations about the new policeman in their final report: "police officers must be individuals who, out of their morality, honesty and prudence, naturally attract the sympathies of the public". ${ }^{44}$ The Lisbon Civil Governor had employed a similar wording two years earlier, stressing that the police force in a capital city should be made up of agents with "the necessary sagacity and politeness, [essential qualities] in this type of service". ${ }^{45}$ When discussing the Polícia Civil project in Parliament, Dias Ferreira, one of the then main opposition figures, joked about this: "They are always the nicest creatures, these 'guards' or 'police officers'! (Laughs) (...) [The bill] is so tight in these [recruitment] conditions that becoming a policeman means meeting more conditions than being admitted to holy orders". ${ }^{46}$ The minister, Martens Ferrão, replied by pointing to the example of foreign countries, stating that similar requirements were applied all across Europe..$^{47}$ Meeting all these conditions did prove more complex in practice than simply submitting a legal statement, particularly in regards to the ability to read and write ${ }^{48}$ However, it is important to note that what was actually at stake was the re-conceptualisation of the policeman ideal and, even while having little or no real effect at the time, this would have substantial long term implications and effectively change the individual policeman's role.

This idealisation of the policeman also reflects a central aspect of the police modernisation process: a policeman who stands apart from both the soldier and the part-time agent and converges on the status of civil servants. The linking of high moral expectations from policemen with the emphasis on good relations with the public demonstrates how Portuguese politicians were aware that the relationship between authority and citizens, between the police and the policed, was not just one-way but one of mutual trust in any liberal society. The insistence on a policeman maintaining self-control, i.e. they would not only deploy more restrained usage of force but they would also be more easily managed, testifies to politicians' concerns over the concrete means by which power was exercised. The intention was to make policemen not only refrain from using unrestrained force but such policemen would also be easier to manage. Politicians recognised that the legitimacy of police authority was not only based on the law and not merely a power granted by law but was also a process of legitimacy arising from the interactions established between

\footnotetext{
43 IAN/TT-MR, Mç.3027, Without Number.

44 DCD, 22 June 1867, p. 2125.

45 IAN/TT-MR, Mç.1761, L ${ }^{\circ} 15, \mathrm{~N}^{\circ} 1761$.

46 DCD, 22 June 1867, pp. 2127-2128. The terms of admission into the police force were: strength and "good looks", between 22 and 40 years old, literate, numerate, with a recognised good reputation, having served in the army and signing a 5 year contract.

47 DCD, 22 June 1867, p. 2128.

48 Santos (2006).
} 
the law enforcement authorities and the population in general. ${ }^{49}$ Policemen should uphold greater moral prestige that would enable them to legitimate their actions and decisions in the eyes of the population. However, these new policemen were not acting in isolation; it was in fact the institutional and bureaucratic framework that would ensure that they effectively acted as expected.

It was this institutional and bureaucratic framework that made development of the 'new policeman' possible. Both in the case of the Polícia Civil and the Guarda Civil, "unity of action" 50 became a central argument as part of the more general "integrated definition of the key functions of the state", ${ }^{51}$ processes which characterise a modern administrative structure. In this respect, the case of police reform encompasses two interlinked but distinct questions. On the one hand, there was the process of political centralisation; the transformation of the police force was designed to provide the centre of power with greater control over policing. In conjunction with the new institutional ideal types - civilian police forces in the cities, the gendarmerie in the countryside - this corresponded to that objective. On the other hand, there was the development of the 'organisational body' concept seeking to build up organisations with their internal relationships formalised along bureaucratic lines so as to achieve the desired levels of efficiency. The search for a new type of policeman in fact represented one facet of the search for a new paradigm for police institution and organisation in which political and operational control became the essential factors. Within the larger rationalisation process of the state administration that was undertaken in the nineteenth century, the period under study here proved a pivotal moment with regard to the integration of the Portuguese police and policing into the bureaucratic model.

Although not directly accountable to the Interior Minister, the Polícia Civil would be directly controlled by civil governors who were themselves effectively under the control of the government. Organisationally, the official regulations of the new police forces provided a fairly detailed definition of the functions and hierarchical positions of all police employees. Every member within the organisation was assigned a clearly defined set of duties and obligations. Thus, police commissioners (at the top of the organisation), heads of police stations (the connection between the top and everyday operations), sergeants (cabos) (the policemen of the policemen) and the police officers (the police on the street) should all know in advance what to do and, just as importantly, what not to do. In fact, while a hierarchical organisation is clearly discernible, the interdependence between the various levels was a central aspect of the new Lisbon and Oporto police forces, thus introducing a bottom-up dynamic.

\section{DEFINING 'PUBLIC SAFETY' AS A SPHERE OF ACTION}

One central aspect of the police reform process focused on the institutional and organisational characteristics of the new police forces; another side of this same

\footnotetext{
49 A similar type of discourse took place in Italy with the new policeman figure devised in clear opposition to the despotic sbirri, Simona Mori (2012, pp. 104-106).

50 Portaria Ministério Reino, 07-09-1863; DCD, 22-06-1867, p. 2125.

51 Hespanha (2004, p. 288).
} 
problem involved identifying the actual causes of insecurity that would in turn be the issues subject to police intervention. Thus, some discussions, whether public or internal to the government revolved around defining police functions. In the case of the urban civil police, the report from the parliamentary commission, which followed the study of the 1867 proposal, attributed the new civil police force with multiple functions: "helping the administration, assisting the criminal justice system, and because it would be inconvenient to have a separate municipal police" the criminal justice system would also become a responsibility for the new police and thus "the sphere of its duties is very wide". ${ }^{52}$ Policemen were responsible for guarding public spaces, regulating traffic, theatres, meetings and other forms of public entertainment, gambling houses and inns, controlling begging and prostitution, weights and measures and all the provisions of municipal bylaws, overseeing the licenses of foreigners as well as gun possession..$^{53}$ This classification of police duties represents the formal outcome of the government defining 'public safety', a sphere that constituted the core of the policing role. The following section sets out how five different but interconnected dimensions of what was conceptualised as 'police functions' influenced police reform in this period: public order, criminal justice, the state's administrative power, municipal policing and the conception of police as a public service. All were areas that underwent significant changes during this period and shed light on how the question of police reform emerged and took shape.

Public Order. To understand the scope of 'public safety', it is helpful to begin by distinguishing it from 'public order'. Even though these were and are contingent categories, they also contain their own specificities. Hence, it is possible to draw a line between public order, i.e. the threat of and/or concrete public disorder, and public safety, specifically the daily preservation of physical integrity and property. According to Diego Cerezales, the public order issue began changing in Portugal in the late 1850s and in the 1860s. Situations ranging from the traditional food riots, experienced in Lisbon as late as 1856, through to politicised protest movements such as the Christmas Riots reveal the emergence of new contours in the public order problem that might prove politically costly to the government. ${ }^{54}$ Indeed, the problem of public order acquired a new prominence in national political debates. However, while we would note that the Guarda Civil was established in direct response to the tense political climate then prevailing in the country, this was not so much the case with the Polícia Civil. Being very lightly armed, the new urban policemen were hardly perceived as a plausible solution to public order problems. Nevertheless, the Polícia Civil would play a specific role in situations of public (dis)order with Portuguese politicians deeming the mere presence of the Polícia Civil in a local area a deterrent to threats against the public order with their capacity to negotiate with potential troublemakers. However, this does not mean that they were perceived as an effective response to public order problems. The continuation in Lisbon and Oporto of military police forces, whether the new Guarda Civil or, as it turned out, the Guarda Municipal, was in fact designed to ensure an effective response to outbreaks of civil unrest in society. Whilst attributed a role in situations involving

$52 \quad$ DCD, 22 June 1867, p. 2125.

53 Law 02 June 1867 , art. $12^{\circ}$ and Regulation 14 December 1867 , art. $18^{\circ}, 54^{\circ}$ and $55^{\circ}$.

54 For a comprehensive analysis of this subject, see (Cerezales, 2008). 
public disorder, the founding of the Polícia Civil stemmed rather from problems and changes happening in the following four categories.

Criminal Justice. During the 1860s, the way the state defined and acted upon crime became a justification for reforming the police system. Unlike other European countries, the Portuguese did not seem to be under widespread perception of rising crime rates. In fact, quite the contrary: the dominant view was that crime rates were lower in Portugal than in the rest of Europe and had been in decline since the 1840s following the turmoil of the civil war of the 1830s. The few statistics available for the period although viewed by contemporaries with deep suspicion as to their veracity, indicate a general reduction in the number of crimes as well as the typical transformation in the pattern of crime with a decline in physical aggression and a rise in verbal violence and property crimes. Although Portuguese crime statistics reveal an approximation to the pattern of crime detected by the authorities in more developed European countries, Portugal contrasted with the rest of Europe in terms of the overall crime rate: whereas crime rose in Europe in this period, it declined in Portugal. ${ }^{55}$ The slow urbanisation process witnessed in Portugal until the 1870 s certainly constitutes the root cause of this contrast. ${ }^{56}$ As with the case of public order, the new urban police forces would act more as a deterrent, preventing criminal activities and reducing the sense of impunity than as a straightforward means of repressing crime. Above all, the transformation of the police system reflected a political project involving broader and more certain state intervention and control over criminality. Portuguese politicians were here in keeping with a common transformation in European penal policies. Greater humanity and a belief in the rehabilitation of criminals as shown by the grading of penalties also meant that the population needed to be reassured that criminals were actually brought to justice. ${ }^{57}$ In fact, the period under study here proved crucial in the building of a modern criminal justice system in Portugal.

The first modern penal code only got approved in 1852 and was immediately acknowledged as in need of reform. Hence, a process of criminal law reform was set in motion from the mid-1850s onwards..$^{58}$ This came to a conclusion on 1 July 1867, one day prior to the founding of the Polícia Civil, with the promulgation of the Sentencing and Prison Reform Act. The new Criminal Code officially adopted the 'modern' penitentiary system and enacted the much-celebrated abolition of the death penalty, which for the Portuguese political elite was the true indicator of the liberalism of the new code. However, one needs to be careful when placing police reform in the context of reform of the criminal justice system. Although police reform was naturally integrated into this process, in fact, the parliamentary debates on these two issues rarely crossed. In other European countries - such as England Robert Peel's launch of the Metropolitan Police - was part of the rationalisation of the whole of the criminal justice system. In Portugal by contrast, the politicians involved in the debates on reforming criminal law or the penitentiary system were

Vaz (1998, pp. 132-138).

56 Silva (1997, p. 787).

57 Emsley (2007, pp. 160-178).

58 Marques (2005, pp. 56-73). 
rarely, if ever, involved in the debates on police reform..$^{59}$ While police reform emerged largely from the practical experience of inefficiency and in response to rising expectations to efficiency, penal reform was anchored in the emergence of specialised criminological knowledge that hardly touched the police debates. Furthermore, in terms of legal reform, the Civil Code was approved in early July 1867, completing a project intended to establish state hegemony in the regulation of social relations with the enactment of the Napoleonic-inspired codes. However, in addition to the written laws, contemporary decision makers felt that practical structures needed to develop before they could effectively put this regulatory power into practice.

The administrative power of the state. It was by adapting the French prefectoral model that the Portuguese state apparatus developed a significant proportion of its administrative capacities. The 1840s witnessed an increase in the functions of the civil governors that covered almost all areas of state intervention. In the 1850s, with the advent of specialized state agencies, police functions became a dominant area of civil government competences. ${ }^{60} \mathrm{~A}$ wide range of 'urban life' issues such as vagrancy, control of public entertainments, carnival practices, vendors' cries and street musicians, gambling and closing hours were subject to increasingly detailed regulations emanating from the Civil Governors. However, just as these functions became increasingly detailed, so did the complaints from the civil governors about the limitations of their operational capacity to fulfil the myriad of police functions for which they were now responsible. In Lisbon, from the mid-1850s, the civil government began to form what was referred to in the press in the early 1860s as 'the civil government police'. Without any official legislative act, this force was composed of eighteen members in 1865 and later integrated into the Polícia Civil. ${ }^{61}$ The money to pay these agents came from the amount registered in the state budget under the heading of 'Preventive Police' that otherwise served to pay political informants in addition to financing criminal investigation. Somehow, the infrastructure of state police power began to grow out of such micro developments.

One of the growing concerns of the Lisbon Civil Government was the enforcement of moral standards in the public space. Prostitution, in particular, represents a paradigmatic example of the rise of police control as exercised by the Governo Civil. From the 1840s onwards, arguments in favour of regulating prostitution through a system of tolerance were frequently voiced in books and pamphlets or in the press. ${ }^{62}$ Public prostitution, the legalisation of prostitution by introducing prostitute registration, medical inspections and police surveillance, was seen as 'a necessary disorder' ${ }^{63}$ In Lisbon, however, it was only from 1858 onwards that the authorities began to produce the regulations and mobilise the resources to enable effective legislative implementation. In 1862, discussions inside the Ministry of the Interior revealed that the resources devoted to the control of prostitution were

\footnotetext{
$59 \quad$ Emsley (1983, pp. 59-61); Emsley (2007, pp. 107-110).

60 Tengarrinha (2002, pp. 143-162).

61 IAN/TT-MR, Mç.3035, Lำ15, No 1761.

62 For example, Francisco Ignácio dos Santos Cruz, Da Prostituição na Cidade de Lisboa, (Lisbon: Typ. Lisbonense, 1841).

63 Relatório sobre a prostituição pública no ano de 1862, IAN/TT-MR, Mç.4538-A.
} 
clearly insufficient. Subsequently, and already within the context of police reform proposals, the civil governor reformulated the system of control of prostitution. In early 1865 , the 1858 Regulamento was reissued only a few months before the promulgation of a new version in greater detail and in accordance with the new police force which was then being developed in the Ministry ${ }^{64}$ After decades of discussion, the system of tolerated prostitution became a reality in the $1860 \mathrm{~s}$. The issue of prostitution most notably linked regulatory reform to reforms of institutions and the enforcement of power even if, in general, the actions of the Lisbon civil government stemmed more from adapting to a new operational reality. Moreover, there was another public authority where a very similar process was also taking place, namely the municipality of Lisbon.

Municipal Police. The division of power was always very blurred between state authorities at the central and local levels, i.e. between the Governo Civil and the Lisbon municipality. Thus, while some police powers emerged within the sphere of the central state, others remained under the city's municipal jurisdiction for no other reason than tradition. In this respect, the 1860s marked the beginning of an intense process of construction and reform of Lisbon's urban environment. ${ }^{65}$ However, the state's attention was not only concentrated on control of the built environment; there was another set of concerns around urban modes of living and daily lifestyle practices ${ }^{66}$ Although the municipal police category in Lisbon also spanned areas of public health control, attentions converged on the surveillance of behaviours in the public domain. The street, as an environment, began to change around this time and would undergo radical transformation over the following decades. Firstly, the emerging middle classes were more willing to adopt public spaces as sites for socialising. The formation of the liberal public sphere also included a new emphasis on social practices in public spaces. Going out, strolling on the promenade, frequenting cafés and theatres, seeing and being seen were core aspects to the social affirmation of the middle classes. However, in order for such social activities to take place, it was necessary to ensure safety, especially because many of these activities happened after nightfall, which was perceived as a particularly dangerous time. On another level, the concept of the street emerged as an arena for circulation and mobility; the function of the street in a rationally organised, capitalist society seeking economic development. Finally, the streets remained a place where the working classes lived, worked, stole, begged and they found their traditional access to the public space increasingly under threat.

In Portugal, the role of public authorities in managing this place of conflict was first assumed by authorities at the local level. It was at the end of the 1840s that the Lisbon municipal services integrated a section of 'municipal police and bylaws' which was overseen by a zelador. Initially, there was only one zelador but, over the years, the number gradually increased and a 'body of municipal zeladores' began to get noticed by the municipal bureaucracy and by the press. In October 1865, this

\footnotetext{
${ }_{64} \quad$ Regulamento policial das meretrizes e casas de toleradas da cidade de Lisboa em 30 de Julho de 1858, (Lisbon: Imprensa Nacional, 1865); Regulamento policial das meretrizes e casas de toleradas da cidade de Lisboa em 1 de Dezembro de 1865, (Lisbon: Imprensa Nacional, 1865).

65 Lousada (2005).

66 Baldwin (1999).
} 
body contained 44 members. ${ }^{67}$ The zeladores were in charge of enforcing bylaws that covered all aspects of city administration. During the 1860s both zeladores and their bylaws would become ever more specifically directed at controlling public spaces. The 'service assignments' (escalas de serviço) published in the official journal of the municipality demonstrate how these men were assigned to the city's main squares and thoroughfares. In the early 1860s, Lisbon had no code of bylaws in contrast to many other municipalities in the country. Hence, one of the priorities of the city authorities became the creation of a legal document gathering and summarising all the municipal bylaws. For practical purposes, the chief zelador was put in charge of this project and referred to as the 'author' ${ }^{\prime} 8$ of the code which, despite being drafted in the early 1860 s, only came to be approved in $1869 .{ }^{69}$ This code marked a break with the bylaw codes that existed in the country at that time. While other codes had a classical structure regulating subjects such as "morality", "cleanliness", "wastelands", Lisbon's new bylaw code focused mainly on controlling the streets and the means of circulation. Of the fourteen chapters in the code, the first seven were devoted to the organisation and regulation of practices taking place in public spaces.

The centralisation of the municipal police force in the Polícia Civil was seen by central and local authorities as a natural step within the context of police reform. Contrary to that the centralisation taking place in other areas of municipal administration, where the entire decade was marked by constant conflict between the central and local authorities, the incorporation of the body of zeladores into the new urban civil police caused no frictions; by 1868 most zeladores were in fact already integrated into the Polícia Civil. After the 1863 proposal for a Lisbon civil police force, the government issued an ordinance (portaria) warning the municipality of the changes under preparation for the organisation and structuring of policing within the city. The municipality immediately agreed, noting that it would always maintain the power to enact bylaws. The relationship between the municipality and the central state was in this regard one of close collaboration. For example, during the visit of Queen Isabella II of Spain in December 1866, the body of zeladores policed the city under the command of the Civil Governor. While it is true that the nineteenth century was marked by the transfer of police powers from local to central authorities, this was not an intrinsically contentious process. ${ }^{70}$

Police as a public service. Another category defining police functions was the dimension that the police force existed in order to provide certain services to the general population. This included not only safety in the strict sense of defending persons and property but also a component identified as the "aid business" ${ }^{71}$ It is this latter aspect that we explore here in order to explore how the police would appear, for example, to the working class not only in the form of punishment and control but also as an agent whom they could call upon for help in case of urgent need.

67 IAN/TT-MR, Mç.3035, $\mathrm{L}^{\circ} 15, \mathrm{~N}^{\mathrm{o}} 1761$.

68 Archivo Municipal de Lisboa (Official Journal of Lisbon's Municipality) [AML], No408, 26-101867, p. 3297.

69 Código de Posturas da Câmara Municipal de Lisboa, (Lisbon: Typographia do Jornal do Comércio, 1869).

$70 \quad$ Emsley (1999a, p. 41).

71 Emsley (1983, p. 4); Monkkonen (2004, p. 55). 
A case that may help illustrate this aspect of public safety proved a torment to all Civil Governors of Lisbon from at least the late 1850s : the transport of the sick and injured to hospital. As they did not seem especially concerned over the enforcement of city bylaws, the men from the Guarda Municipal were not very keen on using the stretchers from their stations for this purpose. Instead, they preferred forcing this task unto the city's water carriers, mostly from the Spanish province of Galicia. Within this framework, the Spanish embassy was to make frequent complaints about acts of violence by the Guarda Municipal over the decade..$^{72}$ In August 1860, the number of patients arriving in Lisbon by the still recent railway (inaugurated in 1856) for treatment at the main city hospital, Hospital S. José increased daily. Tired of the constant conflicts between water carriers, the Guarda Municipal and Cabos, and in an attempt to "prevent those who witness it blaming the authorities for not providing" this service, the regedor of a nearby parish complained to the neighbourhood administrator. ${ }^{73}$ Over the next year, the Interior Minister and the Civil Governor discussed the issue through regular exchanges of correspondence. In June 1861, Sá Nogueira, who was very active in the parliamentary discussions about the police but here in the role of Lisbon Civil Governor, drew up a regulation which assigned this service to the charity of the Holy House of Mercy. However, this institution soon declined its responsibility for this service, stating that it was a task for the administrative authority. ${ }^{74}$ Nothing further was done and the conflicts persisted until two years later, in 1863, the Confraternities, another charity association, were called upon to fund the service but again without much success. The establishment of the Polícia Civil in 1867 was a direct response to this problem. The invoice (guia de transporte) for transporting sick and injured people was one of the first printed forms bearing the heading "Polícia Civil de Lisboa".

Despite still being perceived as charitable services, the notion that the state was responsible for providing some form of welfare to the population through the police gained more precise, practical and socially inclusive contours. Closing off entranceways after midnight or calling midwives, for example, would in the future become police functions stipulated by law. Furthermore, the notion of public service was in fact extended and influenced the transformation of the entire concept of city government, with a "more demanding public" clamouring for the "facilities for which it pays" such as lighting, markets, public baths or the police. ${ }^{75}$

Public order, criminal justice, the administrative power of the state, municipal police and the notion of public service were all to a greater or lesser extent independent spheres of action even while converging to shape the duties of the new police force. However, although they characterised what the new police force was supposed to do, they did not define how the police force was supposed to perform these duties.

\footnotetext{
For example in 1863, IAN/TT-MR, Mç.3022, Lำ14, Nº737.

IAN/TT-MR, Mç.2981, L ${ }^{\circ} 12, \mathrm{~N}^{\circ} 701-753$.

IAN/TT-MR, Mç.2981, Lº 12 , Nº701-753.

75 AML, n²14, 06 February 1864, p. 1712.
} 


\section{RATIONALE OF POLICING: PREVENTION AND EMERGENCY}

Police reform also reflected on the State adopting new strategies for intervening in society and new modes of action for the agents of public authority. Were the new institutions to achieve their purposes, they needed to adopt new forms of rationale. As already noted, parliamentary debates concerning the Christmas Riots represented an initial stage in placing police reform on the political agenda. The discussion was also marked by a lively debate on the concept of police prevention in a liberal society. Fontes Pereira de Melo, former and future prime minister but then on the opposition benches, criticised the government for not having taken preventive measures, which resulted in their having to resort to the use of force after the events had already begun. According to Fontes, the main purpose of policing should be prevention rather than suppression, the correct 'art of government' ${ }^{76}$ Aires Gouveia, on the government's side, responded to Fontes' 'theory of prevention' by inquiring, "where would this principle, this theory of prevention, already rejected by everyone, take us if not to the lack of freedom?"'77 This discussion continued over the following days between those advocating preventive policing and those regarding such as an unacceptable attack on freedom. Finally, Morais de Carvalho, Minister of Justice, put an end to the dispute by introducing a distinction between oppressive prevention, typical of the Old Regime, and a new form of prevention that constituted guaranteeing public safety: "if [prevention] is an administrative police that cares for public safety, the maintenance of individual rights and property of citizens, stopping its action exactly where it begins attacking the freedoms of citizens, that is the police I want for my country" ${ }^{78}$ Despite some recurrent minor political quarrels, this notion became a point of consensus among Portuguese politicians.

Prevention became a prominent political issue in Portugal in the 1860s especially through discussions on how to go about maintaining public order, but it was in relation to crime that the issue gained visibility throughout Europe. From the early nineteenth century, the term preventive police entered the vocabulary of European police institution reformers. The concept began to circulate more timidly in juridical circles in Portugal around that time. ${ }^{79}$ Later in the century, the new penal code that emerged with the Liberal regime was essentially a 'preventive penalty' ${ }^{80}$ And even in the maintenance of public order, the prevention rationale was increasingly present in the practices of the military authorities. ${ }^{81}$ The idea of preventive police emerged in Portugal in a more concrete form with the new political elite of the liberal regime and had in the Regeneration period the ideal ground for consolidation. Prevention meant the increased presence and visibility of policing, which was believed to serve as a deterrent. This rationale cannot, however, be limited to crime and public order. The prevention rationale spanned all areas of police intervention and even state action in general. Prevention was an ever present rationale whether in the sanitary inspection of prostitutes or in the greater surveillance of public thoroughfares in order to prevent

\footnotetext{
76 DCD, 21 January 1862, p. 254.

77 DCD, 23 January 1862, p. 252.

78 DCD, 31 January 1862, p. 351.

$79 \operatorname{Vaz}(1998$, p. 33).

80 Marques (2005, p. 36).

81 Cerezales (2007, pp. 43-46).
} 
traffic accidents. And while the field of public order and crime prevention focused on specific groups - demonstrators and criminals - in its broadest sense, preventive surveillance was extended to a wider social spectrum: a policed society. Only the belief that the authorities were present and preventing, would endow the middle classes with a real sense of security. This increased surveillance could, however, only be carried out by the new policeman type discussed above.

Whilst the first rationale was to prevent any occurrence of acts threatening public safety, a secondary reasoning stemming from the first was that the police force had to be ready to act as quickly as possible were such acts to occur. In the social sciences, the concept of emergency is not new as a rationale for police action. Since the 1960s, sociologists and anthropologists, working on policing practices, have acknowledged that a central dimension of police work is based not so much on what the law prescribes, but on a readiness for action that leads them to act on a wide range of events. Egon Bittner argued that the role of police may best be explained as acting on "something-ought-not-to-be-happening-and-about-which-something-ought-tobe-done-NOW". ${ }^{82}$ According to this author, there are two dimensions to policing emergencies. One consists of temporally longer processes, i.e. events that trigger a police response but understood by the police and other state officials as an interim solution and seen, for example, in some assistance functions. Another dimension is the 'rapid reaction' rationale to problems such as a medical emergency or fire danger warnings. Unlike prevention, emergency is a dimension that historians have not attributed due importance. When mentioned, the subject is usually addressed as follows: on the street, prepared to prevent crime, policemen end up acting on many other issues related to everyday life. Thus, even when this dimension is considered, it is pictured as a result of the policing context, as a collateral effect, and not as part of the political project of modernising the police. The reform of the police in Portugal during these years demonstrates, however, that this was an aspect explicitly considered in the political project.

The expression 'a police ready any time, for any event', which was put forward by the parliamentary committee to characterise the Policia Civil, thus reflects the relationship between a vaguely defined sphere of competences and a rationale of emergency. For example, in the legislation passed on 2 July 1867, this dimension ended up in the role assigned to police commissioners; one of their tasks was "to be immediately present at all extraordinary police cases" even while there is no definition as to what these extraordinary cases might be ${ }^{83}$ What we encounter here is the discursive substantiation of a change in the idea of police practice, from reactive to proactive, a change extending throughout the entire extent of the modernisation process of polices.

\section{CONCLUSION}

Between December 1861 and January 1868, three projects were presented by the Portuguese government to parliament proposing the foundation of urban civil police forces in addition to the establishment of a national gendarmerie force. These

\footnotetext{
$82 \quad$ Bittner (1975, p. 30).

83 Law 02 July 1867 , art. $12^{\circ}$, al.11 ${ }^{\circ}$. My emphasis.
} 
projects reflected a multiplicity of on-going debates both in parliament, in the state apparatus and among the general public. The issue of police reform was certainly not new in 1861. On the contrary, it had appeared regularly in political debates since the rise of the liberal regime in 1834. However, events such as the Christmas Riots of 1861, the nationwide threats to public order in 1862 and the International Exhibition in Oporto in 1865 kept reform of the police system constantly on the political agenda. Nevertheless, the problem was not only linked with the dynamics of immediate events; indeed, deeper changes were at stake.

During the 1830s and 1840s, a modern concept of 'police' - professional bodies subject to the principles of the law - was already well known to the Portuguese political elite. However, political and social instability prevented durable transformations. Only with the stability achieved after the 1851 Regeneration movement did the introduction of wide reaching reforms become feasible. Thus, the debates and changes introduced during the 1860s decisively marked the transformation of the Portuguese police system, particularly in terms of urban policing. This reform consisted of a continuum between institutional and organisational change and a concept of public safety that focused on the full range of everyday urban life. Nevertheless, Lisbon and Oporto, where the concrete results of this reform took place, did not experience growth rates similar to those recorded in other European cities over this period, and therefore escaped the pressures from industrialisation and urbanisation that characterised police reform processes in other European cities. Instead, reform was driven by a cultural transformation of the ideal of the State (its institutional forms, types of agents and functions). At the same time, the emphasis on public safety was influenced by new standards of urban living emerging among the political elites, influenced by certain perceptions among these elites, directly observed or through representations, of policing in other countries.

While discussing the spread of uniformed police in the cities of United States during the nineteenth century, Eric Monkkonen notes that after the initial influence of the Metropolitan model, there was a 'diffusion process', with cities looking to innovations introduced in neighbour cities. He concludes that "[i]f each city had adopted a uniformed force only after a riot, changing crime rate, or the need for a new kind of class-control agency, many places would not today have a uniformed police force" ${ }^{84}$ At a transnational level, the same happened in Europe. In Portugal, terms like guarda civil or guarda campestre were only applied because they evoked foreign examples known to the political elite and to middle-class newspaper readers. Images of Europe populated by gendarmes or by professional 'Bobbies' on the more demanding urban streets - "from Badajoz to Russia" - were deployed as key discursive resources and guidelines for action throughout the process of police reform.

Gonçalo Rocha Gonçalves Centro de Estudos de História Contemporânea / ISCTE Lisbon University Institute $A v^{a}$ das Forças Armadas, 1649-026 Lisbon, Portugal goncalo.goncalves81@gmail.com

$\overline{84}$ Monkkonen (2004, pp. 55, 57). 


\section{BIBLIOGRAPHY}

Baldwin, P., Domesticating the street: The Reform of public space in Hartford, 1850-1930, Columbus, Ohio State University Press, 1999.

Bittner, E. Bish, R., The functions of the police in modern society, Seattle, University of Washington Press, 1975.

Catroga, F., O poder paroquial como "polícia" no século XIX português, in Marques, P., Almeida, P. (Eds), Lei e ordem: justiça penal, criminalidade e polícia, séculos XIX e XX, Lisbon: Livros Horizonte, 2006, pp. 105-130.

Cerezales, D., O princípio da autoridade e os motins anti-fiscais de 1862, Análise Social, 2007, XLII,182, pp. 35-53.

Cerezales, D., Estado, Régimen y Orden Público en el Portugal Contemporáneo (1834-2000), Madrid, Universidad Complutense, PhD Thesis, 2008.

Cunha, C., A “Janeirinha” e o Partido Reformista: Da Revolução de Janeiro de 1868 ao Pacto da Granja Lisbon, Colibri, 2003.

Deluermoz, Q., Présences d'État: Police et societé à Paris (1854-1880), Annales HSS, 2009, 64 année, 2, pp. 435-460.

Denys, C. (ed.), Circulations policières 1750-1914, Villeneuve d'Ascq, Presses Universitaries du Septentrion, 2012.

Emsley, C., Policing and its context 1750-1870, London, Macmillan, 1983.

Emsley, C., A typology of nineteenth-century police, Crime Histoire \& Sociétés / Crime, History \& Societies, 1999a, 3, 1, pp. 29-44.

Emsley, C., Gendarmes and the state in nineteenth century Europe, Oxford, Oxford University Press, 1999b.

Emsley, C., Crime, Police, \& Penal Policy: European Experiences 1750-1940, Oxford, Oxford University Press, 2007.

Hespanha, A., Guiando a mão invisível: direitos, estado e lei no liberalismo monárquico Português, Coimbra, Almedina, 2004.

Hughes, S., Poliziotti, Carabinieri e "Policemens": il booby inglese nella polizia italiana, $L e$ Carte e la storia, 1996, 2, pp. 22-31.

Johansen, A., A Process of Civilisation? Legitimisation of Violent Policing in Prussian and French Police Manuals and Instructions, 1880-1914, European Review of History - Revue Européenne d'Histoire, 2007, 14, 1, pp. 49-71.

Knepper, P., The invention of international crime: a global issue in the making, 1881-1914, Basingstoke, Palgrave, 2010.

Lawrence, P. (ed.), The New Police in the Nineteenth Century, Farnham, Ashgate, 2011.

Liang, H., The rise of modern police and the European state system from Metternich to the Second World War, Cambridge, Cambridge University Press, 2002.

Lousada, M., Una nuova grammatica per lo spazio urbano: la polizia e la città a Lisbonna, 1760 - 1833, Storia Urbana, 2005, 108, pp. 67-85.

Marques, T., Crime e Castigo No Liberalismo em Portugal, Lisbon, Livros Horizonte, 2005.

Monkkonen, E., Police in Urban America 1860-1920, Cambridge, Cambridge University Press, 2004 [1981].

Mori, S., Becoming a policemen in nineteenth-century Italy: police gender culture through the lens of professional manuals, in Barrie, D., Broomhall, S. (Eds), A History of Police and Masculinities 1700-2010, London, Routledge, 2012, pp.102-122.

Philips, P., "A New Engine of Power and Authority": The Institutionalisation of LawEnforcement in England 1780-1830, in Gatrell, V., Lenman, B., Parker, G. (Eds), Crime and the Law: The Social History of Crime in Western Europe since 1500, London, Europa, 1980, pp. 155-189. 
Santos, M., Bonfim - séc. XIX: a regedoria na segurança urbana, Cadernos do Bonfim, 2001, 1, pp. 1-25.

Santos, M., A introdução da polícia civil em Portugal: entre projectos e realidades, os equívocos de uma política de segurança, in Marques, Almeida, P. (Eds), Lei e ordem. justiça penal, criminalidade e polícia, séculos XIX - XX, Lisbon, Livros Horizonte, 2006, pp. 131-145.

Silva, A., A evolução da rede urbana portuguesa (1801-1940), Análise Social, 1997, XXXII, 143-144, pp. 778-814.

Smith, P., Policing Victorian London: political policing, public order, and the London Metropolitan Police, Westport, Greenwood Press, 1985.

Tengarrinha, J. (ed.), História do Governo Civil de Lisboa, Lisbon, Governo Civil Lisboa, 2002.

Vargues, I., Torgal, L., Da Revolução à Contra-Revolução: Vintismo, Cartismo, Absolutismo. O Exílio Político, in Torgal, L., Roque, J. (Eds), História de Portugal: o liberalismo (1807-1890), Lisbon, Estampa, 1998, pp. 57-76.

Vaz, M., Crime e Sociedade: Portugal na segunda metade do século XIX, Oeiras, Celta, 1998. 